\title{
The Influence of Motivation's Component for The Self Esteem Aspect on Nursing Student in Faculty of Nursing Universitas Jember
}

\section{Fitrio Deviantony ${ }^{1 *}$, Dini Kurniawati², Emi Wuri Wuryaningsih ${ }^{3}$}

\author{
1,3Mental Health Nursing, Faculty of Nursing, Universitas Jember, Indonesia; fitrio.psik@unej.ac.id (Corresponding Author) \\ 2Maternity Nursing, Faculty of Nursing Universitas Jember, Indonesia
}

\begin{tabular}{|c|c|}
\hline Article Info: & ABSTRACT \\
\hline Submitted: & The success of academic achievement has a lot of determinants. Social environment \\
\hline 13-06-2021 & background, personal characteristic, and quality of education are only a few of those \\
\hline Revised: & factors (Zimmerman and Schunk, 1989). Own characteristics have a lot of impact on \\
\hline 04-07-2021 & academic success, such as self-esteem, motivation, and also the will for an individual \\
\hline Accepted: & to reach their success. The purpose of this study was to analyze the influence of \\
\hline 05-07-2021 & motivation's component with self-esteem aspect among nursing student in the faculty \\
\hline & $\begin{array}{l}\text { of nursing Jember University. This study employed a cross-sectional study. It involved } \\
84 \text { respondent using purposive sampling technique from a nursing student in the } \\
\text { faculty of the nursing University of Jember from September to November } 2018 \text {. A self- }\end{array}$ \\
\hline & administered questionnaire was designed to collect the data, including \\
\hline DOI: & sociodemographic data, self-esteem scale, and Student motivation Scale. The data \\
\hline https://doi.org/10.53713/nhs.v1i1.23 & $\begin{array}{l}\text { were analyzed using Spearman rank. The results showed that the median of the } \\
\text { motivation was } 50 \text {, with a minimum value of } 28 \text { and a maximum value of } 140 \text {, whereas }\end{array}$ \\
\hline & $\begin{array}{l}\text { the mean value of self-esteem was } 2.46 \text { with a standard deviation of } 0.56 \text {. There was a } \\
\text { significant correlation between motivation and self-esteem ( } p \text {-value: } 0.001 ; r: 0.358 \text { ). }\end{array}$ \\
\hline & $\begin{array}{l}\text { The correlation was weak and positive, which means the higher the value of } \\
\text { motivation, the higher the self-esteem. The correlation analysis revealed that }\end{array}$ \\
\hline (c) (i) () & $\begin{array}{l}\text { motivation has a significant effect on self-esteem. It is show that raising motivation } \\
\text { must be high on the list for an educational program. }\end{array}$ \\
\hline
\end{tabular}

This work is licensed under CC BY-SA License.
Keywords: motivation; self-esteem; nursing student

\section{INTRODUCTION}

Academic success is the purpose of student for seeking knowledge at universities. This problem has a lot of determinants, such as Mental ability, social environment background, quality of education, and personal characteristics. Personal characteristics such as self-esteem and motivation are also crucial for a student to reach their academic success. However, the problem comes when the students do not have enough motivation to be able to achieve academic success. Research has indicated that motivation is one of the significant predictors of academic achievement (Leana-Tas, 2015; Pokay and Blumenfeld, 1990). According to Harter (1983), self-esteem is the value that people attach to their self-descriptions' and it is positively correlated among other variables to academic achievement. Several studies investigate both constructs' relationship with the result (Battle, 1982; Bridgeman and Shipman, 1978; Elliot and Dweck, 1988; Pintrich, 2000). However, research is needed to know that motivation from the student can affect their selfesteem.

Research on motivation has a vital role for identification, programming, and evaluating the process of the educational program. Several motivational theories can be related to student academic success such as goal orientations, expectancy-value framework, and intrinsic-extrinsic approach. According to Schunk et al. (2008), motivation divides into two different types: intrinsic and extrinsic. Students who are intrinsically motivated are curious and focused on the task; on the other hand, students who are extrinsically motivated are interested in the prizes, grades, and so on, more than the job. Usually, there is an expectancy that the college students have higher intrinsic motivation than their extrinsic motivation

Self-esteem is another subject of interest to researchers with college students as a subject. According to Gagne (2000), self-confidence is one of the catalysts that contribute to reaching academic success. Hence, self-esteem is positively associated with educational outcomes, in theory, various research studies about self-esteem and motivation. While Kelly and Colangelo (1984) stated that highly motivation affects self-esteem on the student in junior high school; 
Loeb and Jay (1987) reported that there were no significant results about motivation and self-esteem. Generally, study results indicate that students with excellent extrinsic support have significantly higher levels of self-esteem in comparison with average students. These result so that the motivation and self-esteem have a contrast result, so this study aims to investigate the influence of motivation component for the self-esteem aspect on the nursing student in faculty of nursing, Jember University.

\section{METHOD}

This study used an observational, cross-sectional design. The student in the first semester participated in this study. The study was conducted from September 2018 to October 2018. To determine the required sample size, $G^{*}$ power 3.1 software was employed 14. The analysis generated a sample size of 84 students for small effect size $(\gamma=$ 0.15). The alpha was .05 , and the power(1- $\beta$ ) was .80 . Then, with the additional $10 \%$, the total sample size became 93 Student. Using a purposive sampling strategy, the student was invited to participate in this study.

The participants of this study were selected based on the following inclusion criteria: The student that takes a psychosocial class and the student in the first semester. Meanwhile, the student who takes a remedial course is excluded.

A questionnaire was employed to collect research data from the participants. The questionnaire was used to obtain socio-demographic information, including age, gender, and individual sequence children. Student Motivation Scale (CMS) was employed to measure the student's motivation. It contains 24 items and six subscales (intrinsic motivation, integrated regulation, identified regulation, introjected regulation, external regulation, and amotivation). Seven-level scale was used to measure the items (does not correspond at all= 1-2; corresponds moderately $=3-5$; and corresponds correctly $=6-7$ ) CMS indicated a satisfactory level of internal consistency. Correlations among the subscales showed a pattern which provides support for the self-determination continuum and the construct validity of the scale

The Self-esteem inventory questionnaire is used to collect the self-esteem data. This questionnaire consists of 50 statement items initially. But in this study, the researcher uses 34 statements which have been tested for validity and reliability. Each type of question has favorable items and unfavorable item. The research data were collected from September 2018 to October 2018. After obtaining consent from the participants, a questionnaire was distributed to the respondent which is fulfill the inclusion criteria

The research data were analyzed using Statistical Package for the Social Sciences (SPSS) version 22.0 (IBM, 2015). Quantitative data are presented as means standard deviations (SD) and the qualitative data are presented in terms of frequencies and proportions. Meanwhile, a spearman rank test was used for comparison about the motivation data and self esteem data.

\section{RESULT}

Table 1. Characteristics of respondent by age and sex in Faculty of Nursing Jember University September - October $2018(n=84)$

\begin{tabular}{lll}
\hline \multicolumn{1}{c}{ Variabel } & $\mathrm{n}$ & $\%$ \\
\hline Age & & \\
Mean $=18.87$ & & \\
Median $=19.00$ & & \\
$\mathrm{SD}=1.235$ & & \\
$\quad$ Min - Max $=16-22$ & & \\
Sex & 22 & 26.2 \\
$\quad$ Male & 62 & 73.8 \\
$\quad$ Female & 84 & 100 \\
\hline Total & & \\
\hline
\end{tabular}

Respondent characteristic description are mostly male $(73.8 \%)$ and the rest are male $(26.2 \%)$ the age of respondent was identified. based on table I was found that the median age of respondents was 19 years with a minimum value of 16 and a maximum score of 22 years. 
Table 2. Result of Normality Test

\begin{tabular}{lcc}
\hline \multicolumn{1}{c}{ Data } & $\mathrm{p}$ & Interpretation \\
\hline Age & 0.018 & negative \\
Motivation & 0.000 & negative \\
Self esteem & 0.009 & negative \\
\hline
\end{tabular}

Table 3. Result of Correlation

\begin{tabular}{lccl}
\hline \multicolumn{1}{c}{ Variabel } & $r$ & $p$-value & Correlation \\
\hline $\begin{array}{l}\text { Motivation } \\
\text { Self esteem }\end{array}$ & 0.358 & 0.001 & + (positive) \\
\hline
\end{tabular}

\section{DISCUSSION}

Table 3 explains that there is a significant correlation between the dependent variable (self-esteem) with the independent variable (motivation) where $p$-value $=0.001$, which means there is a significant correlation between motivation and self-esteem. The value of Pearson correlation ( $r$ ) describes that there is a positive relationship between each variable, where the value of $r$ is close to one, this means that the bigger $r$ value has a meaning that the correlation is will be greater. According to the result conducted by Webber (2016), the result is also in line with the results of this study. The researchers revealed that the study showed significance value between motivation and self-esteem in college students, which is this research tested using spearman hypothesis test. The result shown that $p$-value $<0.001$ and correlation are weak $(r)=0.358$. These results mean that between motivation and self-esteem in head trauma patients has a significant correlation. Besides, the r-value that describes the correlation strength explains that SEWS with LOS has a positive correlation.

Shows zero-order correlations for the self-esteem, motivation components, and achievement throughout the entire sample. The correlations ranged from 0.505 to 0.702 . While general, academic, parental, total self-esteem, intrinsic motivation, and achievement exhibited positive relationships with each other, the extrinsic motivation and the desire to please the teacher correlated negatively with achievement.

\section{CONCLUSION}

The correlation was weak and positive which means the higher the value of motivation the higher the self esteem. The correlation analyisis revealed that motivation has significant effect for self esteem. Its is show that raising motivation must be high on the list for educational program.

\section{REFERENCES}

Abdulghani, H. Alkanhal, A. Mahmoud, E. \& Ponnampeuma, G. (2011). Stess and its Effects on Medical Students: a Cross-Sectional Study at a Collage of Medicine in Saudi Arabia. J. Health, Population and Nutrition. 29(5):516.

Achmadin. 2015. Strategi Coping Stress pada Mahasiswa Baru Fakultas Psikologi Universitas Muhamadiyah Malang. http://eprints.umm.ac.id/34265/. [Accessed 12 May 2018].

Amalia, F. (2015). Pengaruh Strategi Coping terhadap Culture Shock pada Mahasiswa Asing Tahun Ajaran Baru 2015/2016 Universitas Islam Negeri Maulana Malik Ibrahim Malang. Skripsi. Malang: Fakultas Psikologi Universitas Islam Negeri Maulana Malik Ibrahim Malang.

Arganata, B. (2017). Kawasan Jember Selatan yang Sarat dengan Kebudayaan Jawa. Jember: LokaKarya. 26 January. Page 1.

Azizah, L, N. (2016). Hubungan Dukungan Sosial Dan Efikasi Diri terhadap Stres Akademik Pada Mahasiswa Baru Fakultas Psikologi UIN Malang Angkatan 2015. Skripsi. Malang: FakultasPsikologi.

Cahyono, H. (2017). Pergeseran Pola Komunikasi di Pedesaan Kabupaten Jember. Skripsi. Jember: Universitas Muhammadiyah Jember.

Devinta, M. (2015). Fenomena Culture Shock (GegarBudaya) pada Mahasiswa Perantauan di Yogyakarta. Skripsi. Yogyakarta: Fakultas IImu Sosial.

Devito, J.A. (2011). Komunikasi Antar Manusia. Tangerang: Karisma Publishing Group.

Febrianto, P. S. (2011). Kajian Strategi dan Prioritas Pembangunan Pendidikan Menengah untuk Meningkatkan Mutu Pendidikan di Pulau Madura. Skripsi. Madura: Fakultasllmu Pendidikan.

Furnham, A. \& Bochner, S. (2003). Culture shock: Psychological Reactions to Unfamiliar Environments. New: Methuen Inc. 